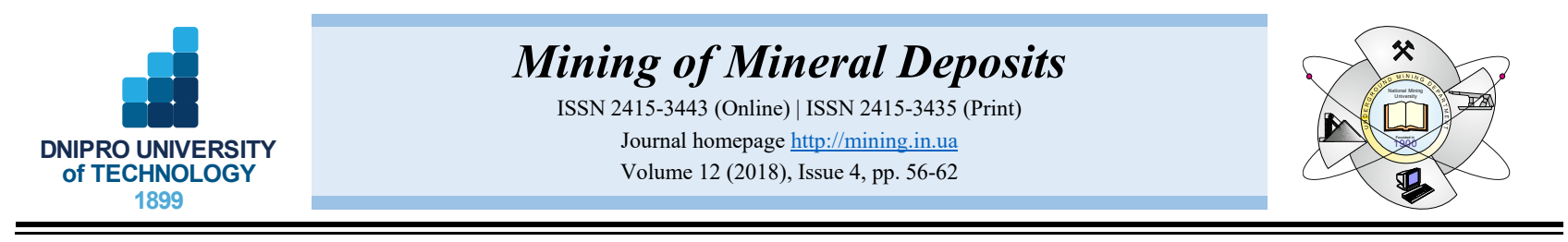

UDC 622.27

https://doi.org/10.15407/mining12.04.056

\title{
CHOICE AND SUBSTANTIATION OF STABLE CROWN SHAPES IN DEEP-LEVEL IRON ORE MINING
}

\author{
M. Stupnik ${ }^{1}$, O. Kalinichenko ${ }^{1}$, V. Kalinichenko ${ }^{1}$, S. Pysmennyi ${ }^{1 *}$, O. Morhun ${ }^{2}$ \\ ${ }^{1}$ Kryvyi Rih National University, Kryvyi Rih, Ukraine \\ ${ }^{2}$ PJSC "Sukha Balka”, Kryvyi Rih, Ukraine \\ *Corresponding author: e-mail psvknu@gmail.com, tel.+380969985358
}

\begin{abstract}
Purpose. The aim of the paper is to select and substantiate stable shapes of crown pillars through determining regularities of rock pressure impacts on their stability depending on the crown shapes, mining depths and iron ore hardness.

Methods. Stress and strain calculations are performed by the ANSYS 16.0 finite element analysis. Triangulation of the $3 \mathrm{D}$ model with a $2 \mathrm{~m}$ side is conducted to build stress and strain diagrams. In accordance with the conditions of the experiment, the models were created for horizontal, tent, arched and inclined stope crowns with the dip varying within a wide range. The assumed values of rock pressure on the ore massif conform to mining conditions of the Kryvyi Rih basin deposits at the depths of 1200 to $1700 \mathrm{~m}$.

Findings. The obtained values of maximum stresses in stope crowns were calculated in respect to mining depth, rock pressure, crown dip, iron ore hardness and relative curvature radius of the arched crowns. It was determined that vertical and inclined compensating rooms should be used in mining rich iron ores at great depths by sublevel caving systems. In case of the room-and-pillar systems used in mining rich iron ores at great depths, a key requirement is to apply tent and arched crowns which provide maximum stability under high rock pressure.

Originality. The research proves that the integrated index of maximum stresses in crown pillars varies from -10 to $+32 \mathrm{MPa}$ at depths of over $1200 \mathrm{~m}$ and is in polynomial and logarithmic dependence on physical and mechanical properties of the ore mass. It also depends on the crown geometry and, in case of the arched crown, acquires minimal values allowing for stable crown pillar exposures at depths reaching $2000 \mathrm{~m}$.

Practical implications. The research results allowed to compile the methodological manual "Choice and substantiation of stable crown shapes in deep-level iron ore mining" for the underground mines of the PJSC "Sukha Balka" and "Rodina" mine of the PJSC "Kryvbaszalizrudkom".
\end{abstract}

Keywords: ore, underground mining, crown pillar, exposures, stresses, stability

\section{INTRODUCTION}

The Kryvbas underground mines produce rich iron ores. Stoping is carried out at the depths of $1200-1450 \mathrm{~m}$, preliminary development reaches $1600 \mathrm{~m}$. Deepening causes considerable increase in rock pressure (Talobre, 1967; Malakhov, 1990; Kalinichenko, 2015), which results in decreased general stability of underground mine workings (Stupnik \& Kalinichenko, 2012; Radouane, Boukelloul, \& Fredj, 2015; Cała et al., 2016), stability of stopes and compensating rooms being a particular cause of concern (Das et al., 2017). Investigations in this field mostly deal with analysis of general stability of underground workings with complex geometry (Stupnik, Kalinichenko, Kalinichenko, Muzyka, \& Fedko, 2015; Das et al., 2017). Indirect methods of determining compressive strength and the elastic modulus of rock samples as well as research into risks of roof collapse are often used to determine stability of mine workings (ASTM, 2009).

At the same time, studies of stability of underground working exposures are the most important (Iannacchione, Batchler, \& Marshall, 2004; Esterhuizen, Dolinar; Ellenberger, Prosser, \& Iannacchione, 2007; Bondarenko, Kovalevskaya, Simanovich, \& Snigur, 2013). Available methodological manuals (Tsarikovskiy, Sakovich, Kishkin, Artemenko, \& Migul, 1994; Vybor i obosnovanie..., 2017) cannot be used for determining parameters of deep exposures. In this regard, special demand is placed on stability of exposed crowns that are the most vulnerable elements of underground workings (Kriev \& Kriev, 2005; ASTM, 2009; Stupnik, Kalinichenko, Pysmennyi, \& Kalinichenko, 2016).

(C) 2018. M. Stupnik, O. Kalinichenko, V. Kalinichenko, S. Pysmennyi, O. Morhun. Published by the Dnipro University of Technology on behalf of Mining of Mineral Deposits. This is an Open Access article distributed under the terms of the Creative Commons Attribution License (http://creativecommons.org/licenses/by/4.0/),

which permits unrestricted reuse, distribution, and reproduction in any medium, provided the original work is properly cited. 
Thus, when designing stopes at great depths, special attention must be paid to stability of the exposed stope and compensating room crowns. Therefore, the present paper is aimed at choosing and substantiating crown shapes through determining regularities of rock pressure impacts on the crown stability depending on its shapes, mining depths and iron ore hardness.

\section{METHODS}

In this paper, stress and strain calculations are performed by the ANSYS 16.0 based finite element technique. Triangulation (division of a 3D model into triangles) with a $2 \mathrm{~m}$ side is conducted to build stress and strain diagrams. Due to the possibility of parallel calculations, the computation process is conducted concurrently, including creation of a stiffness matrix, solution of linear equations, calculation of results via processing with memory sharing and distributing. Additional deep techniques, e.g. the component synthesis mode, the analysis of the cyclic symmetry, submodeling techniques, facili- tate work with large models and systems that represent the stress-strain state of rocks.

It should be noted that, when studying the stressstrain state of the rocks, special attention should be paid to stope shapes, especially to geometry of their crowns. The stress-strain state of rocks produces considerable impact on applied technologies' parameters and the stoping sequence. The obtained information on the character and values of active stresses in the massif, reasons for their changes during stoping enables to assess current conditions and obtain the initial data for enhancing the applied flow sheets and developing the new ones, choosing optimal parameters of stoping and its rational sequence.

In accordance with the conditions of the experiment, models were created for horizontal, tent, arched and inclined crown shapes with the dip varying within a wide range. The accepted values of caved rock pressure on the ore massif $P_{1}, P_{2}$ and $P_{3}$ conform to mining conditions of Kryvbas deposits and correspond to mining at the depths of 1200,1450 and $1700 \mathrm{~m}$. Physical and mechanical properties of the studied ore and waste rocks are given in Table 1.

Table 1. Physical and mechanical properties of the ore and waste rocks

\begin{tabular}{|c|c|c|c|c|c|c|c|c|c|}
\hline \multirow[b]{2}{*}{ Parameters } & \multirow[b]{2}{*}{ Units } & \multicolumn{4}{|c|}{ Ore } & \multicolumn{3}{|c|}{ Rock } & \multirow{2}{*}{$\begin{array}{l}\text { Waste } \\
\text { rocks }\end{array}$} \\
\hline & & $\begin{array}{c}1 O \\
f=3-5\end{array}$ & $\begin{array}{c}2 O \\
f=4-6\end{array}$ & $\begin{array}{c}3 O \\
f=5-7\end{array}$ & $\begin{array}{c}4 O \\
f=6-8\end{array}$ & $\begin{array}{c}1 R \\
f=4-6\end{array}$ & $\begin{array}{c}2 R \\
f=5-7\end{array}$ & $\begin{array}{c}3 R \\
f=8-10\end{array}$ & \\
\hline Young modulus & $\mathrm{MPa}$ & 22000 & 25000 & 28000 & 32000 & 22000 & 33000 & 40000 & 5000 \\
\hline Volume weight & $\mathrm{kg} / \mathrm{m}^{3}$ & 3700 & 3650 & 3600 & 3500 & 2800 & 2900 & 3000 & 2400 \\
\hline $\begin{array}{l}\text { Compressive } \\
\text { resistance }\end{array}$ & $\mathrm{MPa}$ & 30 & 40 & 50 & 60 & 45 & 55 & 80 & 5 \\
\hline $\begin{array}{l}\text { Ultimate tension } \\
\text { stress }\end{array}$ & $\mathrm{MPa}$ & 3.0 & 4.0 & 5.0 & 6.0 & 4.5 & 5.5 & 8.0 & 0.3 \\
\hline Poisson's ratio & - & 0.30 & 0.28 & 0.26 & 0.25 & 0.26 & 0.24 & 0.24 & 0.25 \\
\hline
\end{tabular}

Values of rock pressure on the ore massif that correspond to mining conditions of Kryvbas deposits are given in Table 2.

Table 2. Parameters of rock pressure on the ore massif

\begin{tabular}{cccc}
\hline \multicolumn{1}{c}{ Parameters } & $P_{1}, \mathrm{MPa}$ & $P_{2}, \mathrm{MPa}$ & $P_{3}, \mathrm{MPa}$ \\
\hline $\begin{array}{l}\text { Rock pressure on the } \\
\text { massif: vertical/lateral }\end{array}$ & $7.0 / 2.5$ & $8.5 / 3.0$ & $10.0 / 3.5$ \\
\hline
\end{tabular}

When studying the stress-strain state of the ore massif, special attention is paid to shapes of stopes and stope crowns in particular. To properly compare the obtained results, stopes' dimensions are assumed equal.

\section{RESULTS AND DISCUSSION}

The results of calculating stress fields for various crown shapes are given below. Stress values on isolines are given in $\mathrm{MPa}$. In stopes with horizontal crowns, principal stress values are distributed according to the classical law of stress distribution in rocks. For instance, the maximum compressive stresses are observed in the corners of stopes, whereas tension stresses are detected in the central part of the crowns. Tension stresses are the most dangerous and the most frequent reasons for destructive impacts of rock pressure on mining engineering elements. If the value of tension stresses in a stope crown does not exceed the ultimate tension stress of the ore massif, the crown of this kind remains stable, especially in ores with low fracturing. If the value of tension stresses in a stope crown exceeds the ultimate tension stress of the ore massif, the crown of this kind is predictably instable and tends to form local falls or be completely destroyed.

The calculated values of maximum stresses in horizontal crowns of stopes $\sigma_{1}$ depend on the mining depth $H_{p}$ and the corresponding values of rock pressure for differentiated iron ore hardness are described by the polynomial equations:

- for ore hardness $f=4-6$ :

$\sigma_{1}=2 \cdot 10^{-6} H_{p}^{2}-0.0128 H_{p}+3.056 \mathrm{MPa}$

- for ore hardness $f=5-7$ :

$\sigma_{1}=2 \cdot 10^{-6} H_{p}^{2}-0.0132 H_{p}+2.836 \mathrm{MPa} ;$

- for ore hardness $f=6-8$ :

$\sigma_{1}=2 \cdot 10^{-6} H_{p}^{2}-0.0124 H_{p}+1.076 \mathrm{MPa}$.

The adaptive index of maximum stresses $\sigma_{1}$ in horizontal crowns of stopes dependence on the mining depth $H_{p}$ and differentiated iron ore hardness can be determined by the expression, MPa:

$$
\begin{aligned}
& \sigma_{1}=\left(-4.4394 \ln \left(f_{p}\right)-1.6208\right) \cdot\left(2.2727 \cdot 10^{-7} \times\right. \\
& \left.\times H_{p}^{2}-1.4545 \cdot 10^{-3} H_{p}+0.3472\right) .
\end{aligned}
$$


In stopes with tent crowns, principal stress values are distributed in the following way. Crown shape transformations result in principal stress inversion. Changes in the stress-strain state of the tent crown massif are observed in places where decrease in compressive stress values is registered. Also, no tension stresses are observed.

The calculated values of dependence of maximum stresses $\sigma_{1}$ in tent stopes crowns on the mining depth $H_{p}$ and the corresponding value of rock pressure for various iron ore hardness are described by the logarithmic equations:

- for ore hardness $f=4-6$ :

$\sigma_{1}=28.804 \ln \left(H_{p}\right)-172.05$,

where:

$\sigma_{1}$ - the maximum stress value in tent crowns, $\mathrm{MPa}$;

$H_{p}$ - the mining depth, m;

- for ore hardness $f=5-7$ :

$\sigma_{1}=28.804 \ln \left(H_{p}\right)-171.05$;

- for ore hardness $f=6-8$ :

$\sigma_{1}=25.858 \ln \left(H_{p}\right)-148.3$.

Here, the universally adaptive index of maximum stresses $\sigma_{1}$ in tent crowns of stopes depending on the mining depth $H_{p}$ and the corresponding rock pressure value for differentiated iron ore hardness can be determined by the expression, MPa:

$$
\begin{aligned}
& \sigma_{1}=\left(-0.1354 f^{2}+3.0691 f+19.873\right) \times \\
& \times\left(0.9001 \ln \left(H_{p}\right)-5.3766\right) .
\end{aligned}
$$

Fundamental laws and the obtained results allow to state that tent shapes of crowns are much more stable as compared to horizontal exposures. Calculated values of maximum stresses in arched stopes dependence on the mining depth and the corresponding rock pressure values for various iron ore hardness enabled to establish the following regularities. The value of maximum stresses in crowns varies depending on the value of rock pressure and the arched crown curvature. Arched crowns with the curvature radius equal to a half of the stope width are the most stable.

The results of calculations of maximum stresses $\sigma_{1}$ of rocks during arched crown formation demonstrate that crown stress values vary depending on the rock pressure value and arched crown curvature. In this case the following dependences are obtained:

- for ore hardness $f=4-6$ :

$\sigma_{1}=2.8804 \ln \left(H_{p}\right)-10.405$,

where:

$\sigma_{1}$ - values of maximum stresses in arched crowns of stopes, $\mathrm{MPa}$;

$H_{p}$ - the mining depth, m;

- for ore hardness $f=5-7$ :

$\sigma_{1}=5.4662 \ln \left(H_{p}\right)-28.635$;
- for ore hardness $f=6-8$ :

$\sigma_{1}=5.2211 \ln \left(H_{p}\right)-27.72$.

Analysis of the numerical simulation results allows to conclude that the arched shapes of stope crowns facilitate decrease in maximum stress values. Consequently, as the arch curvature radius increases, the compressive stress values on the crown center decrease. Simultaneously, the maximum stress values are registered in the arch spring.

With the crown curvature radius going to infinite values, the arch center experiences tension stresses. In this case the conceptual pattern of stress distribution in the massif is identical to the strain-stress state of the horizontal crown massifs.

The average dependence of values of maximum stresses in arched crowns of stopes depending on their relative curvature radius is determined from the expression:

$R_{o}=\frac{l_{s}}{2 R_{c}}$,

where

$R_{o}$ - the relative of arch curvature radius of stope crowns;

$l_{s}$ - the normal width of the dead stope, $\mathrm{m}$;

$R_{c}$ - the crown curvature radios, $\mathrm{m}$.

The simulation analysis allows to conclude that dependence of maximum stress values in arched crowns of stopes on the arch curvature radius is described by the following logarithmic equation:

$\sigma_{1 R_{O}}=6.636 \ln \left(R_{o}\right)+9.4$.

Analysis of the results of multifactor experiments enables to determine the universal adaptive index of maximum stresses $\sigma_{1}$ in arched crowns of stopes depending on the mining depth $H_{p}$, relative crown curvature radius $R_{o}$ and differentiated iron ore hardness $f, \mathrm{MPa}$ :

$$
\begin{aligned}
& \sigma_{1}=\left(0.2880 \ln \left(H_{p}\right)-1.0405\right) \cdot\left(6.636 \ln \left(R_{o}\right)+\right. \\
& +9.4) \cdot\left(-5.83 \cdot 10^{-3} f^{2}+0.1325 f+0.4582\right) .
\end{aligned}
$$

Research into dependences of maximum stresses values in inclined crowns on the mining depth and the corresponding rock pressure values for various iron ore hardness produced the following results. Maximum stress values in the crowns under study vary depending on rock pressure and the crown dip. The calculated values of maximum stresses $\sigma_{1}$ in inclined crowns of stopes depending on the mining depth $H_{p}$ and the corresponding value of rock pressure for various iron ore hardness $f$ are described by the logarithmic equations.

In respect to ore hardness, the determined dependences are described by the following equations:

- for ore hardness $f=4-6$ :

$\sigma_{1}=12.144 \ln \left(H_{p}\right)-73.945$,

where:

$\sigma_{1}$-values of maximum stresses in inclined crowns, $\mathrm{MPa}$;

$H_{p}$ - the mining depth, m; 
- for ore hardness $f=5-7$ :

$\sigma_{1}=12.634 \ln \left(H_{p}\right)-77.974$;

- for ore hardness $f=6-8$ :

$\sigma_{1}=11.538 \ln \left(H_{p}\right)-70.707$.

The research results allow to establish the dependence of changes of maximum stress values on the stope crown dip. Values of maximum stresses in inclined crowns are related to the dip angle $\lambda_{c}$ of the inclined crown of the stope and are described by the following polynomial dependence:

$\sigma_{1 s}=-0.0031 \lambda_{c}^{2}+0.5517 \lambda_{c}-9.1692$,

where:

$\lambda_{c}-$ the dip angle of the inclined crown, degrees.

After processing multifactor experiment results, we got the universal adaptive index of maximum stress values $\sigma_{1}$ in inclined crowns of stopes depending on the mining depth $H_{p}$, the crown dip and the corresponding iron ore hardness, $\mathrm{MPa}$ :

$$
\begin{aligned}
& \sigma_{1}=\left(1.0469 \ln \left(H_{p}\right)-6.3746\right) \cdot\left(-0.0031 \lambda_{c}^{2}+\right. \\
& \left.+0.5517 \lambda_{c}-9.1692\right) \cdot(0.2566 \ln (f)+0.5836) .
\end{aligned}
$$

Simulation results analysis leads to the following conclusions. The increased mining depth results in considerable rock pressure growth. In view of the above, special requirements are placed on stability of exposed stopes and compensating rooms as well as on accuracy of designing construction units when stoping at great depths. In this regard, when mining rich iron ores by sublevel caving at Kryvbas underground mines, vertical and inclined compensating rooms should be wider used. At the same time, it is vital to introduce the technology of mining panels with caving ore onto the tent-shaped compensating room. When rich ores are mined by the room-and-pillar method, ensuring stope crown stability is a key requirement. In this case, it is critical to use arched crowns that provide maximum stability in complicated geological and mining conditions.

Sufficiently complete presentation of the technology of forming arched crowns is given in (Tsarikovskii, Sakovich, Kishkin, Artemenko, \& Migul, 1994; Vybor i obosnovanie..., 2017). The conducted research allowed to suggest methods for choosing and substantiating stable crown shapes at underground mines of the PJSC "Sukha Balka". Deposits of underground mines "Frunze" and "Yuvileina", which are parts of the PJSC "Sukha Balka", are represented by rich iron ores with iron content of $46 \%$. Between the mines occur low-grade ores represented by magnetite and oxidized types of ferruginous quartzite (site No. 6).

The geological composition of the deposits of "Frunze" and "Yuvileina" underground mines comprises rocks of Kryvyi Rih metamorphic series of the lower Proterozoic (PR1) and the Archean rocks (AR). There are seven ferruginous and seven schist levels altogether.

Main ore bearing bodies of the iron ore deposits are the Fifth and the Sixth ferruginous levels. Besides rich iron ore deposits of the Fifth and the Sixth levels, "Pivdenna" and "Pivnichna" bodies are also minable magnetite quartzite deposits which are part of magnetite quartzite areas between sites No. 5 and No. 6. Other ferruginous levels are of insignificant thickness, high degree of oxidation and, therefore, not minable.

The deposit of "Frunze" in the Fifth ferruginous level includes ore bodies of the underground mine "Zakhidna of underground mine No. 8", "V - VIII Pivnichna" and "Saksahanka of underground mine No. 2". The Sixth ferruginous level incorporates ore bodies "Diahonalna", "I - III Pivdenna" and "Tsentralna". The ore bodies are pillar- and sheetlike in shape. The main and largest reserves are located in the Fifth ferruginous level. The ore bodies are mainly represented by martite metals. Gothitehematite-martite, dispersed-hematite-martite, gothitehematite ores are represented as "margins" of martite ores. The hardness ratio of martite ores varies from $3-4$ to $11-13$ points (Protodiakonov scale of hardness), that of the enclosing rocks is from $9-10$ to $14-16$ points.

The deposit of "Yuvileina" underground mine is located in the Fifth ferruginous level and contains ore bodies "Holovna" and "Shurfov $42-46$ ". The Sixth level contains ore bodies "Hnizdo 1-2", "Hnizdo 3" and "Tsybulko 76". The ore bodies are stock-, nest- and seamlike in shape. The ore bodies are of $190-1530 \mathrm{~m}$ long along the strike, the horizontal thickness makes $2-42 \mathrm{~m}$, the horizontal ore area is $750-30360 \mathrm{~m}^{2}$. The ore bodies occur according to enclosing rocks and have a northeastern strike and the southwestern dip with the $50-60^{\circ}$ angle. The footwall rocks are made of weakly fractured stable hydrohematite quartzite and instable gothite-hematite and quartz-chlorite schists prone to fall along sheeting planes. The hanging wall contains gothitehematite and martite weakly fractured stable quartzite. The hardness ratio of the ores varies from $4-6$ to $11-13$ points (Protodiakonov scale of hardness), that of the enclosing rocks is from $5-6$ to $11-13$ points.

Considering geological and mining conditions of the ore body occurrence, physical and mechanical properties of ores and enclosing rocks at "Yuvileina" underground mine (PJSC "Sukha Balka"), the sublevel room-and-pillar system with vertical rings of deep holes onto the horizontal compensating room should be applied to mining blocks in accordance with the standard design "Mining systems for Kryvbas underground mines" (NIGRI, 1986).

At "Yuvileina" underground mine, with rich iron ores occurring at the depth of over $1300 \mathrm{~m}$, the use of horizontal crowns in forming undercutting rooms may bring about problems of maintaining stable horizontal exposures. As mining deepens, the growing rock pressure affects stability of horizontal compensating rooms. Possible failures of horizontal crowns result in loss of deep holes' integrity and, therefore, increased amount of oversize pieces of ore. The latter impairs rich ore drawing and extraction indices as well as increases mining costs.

Considering the above mentioned drawbacks and the current mining technology used at underground mines, the authors recommend applying the arched crown. Figure 1 presents a variant of the room-and-pillar system with formation of an arched crown of a stope during stage-mining of blocks recommended for the PJSC "Sukha Balka" underground mines. 
(a)

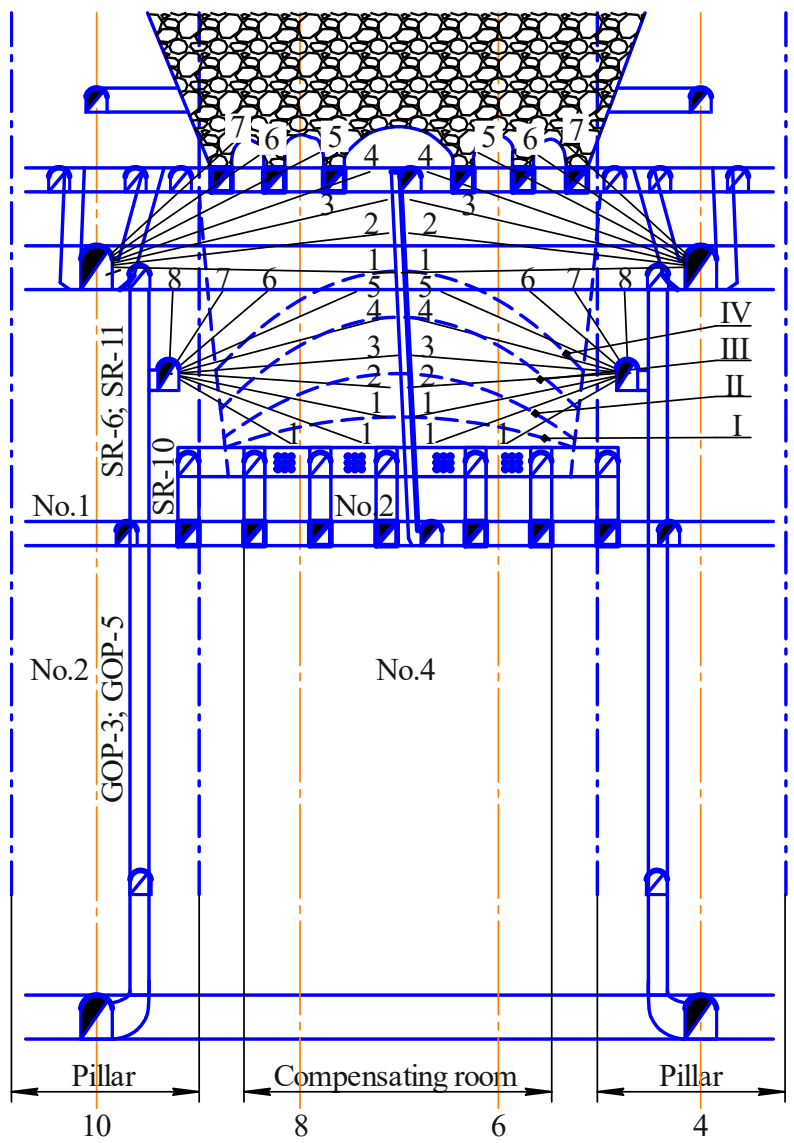

(b)

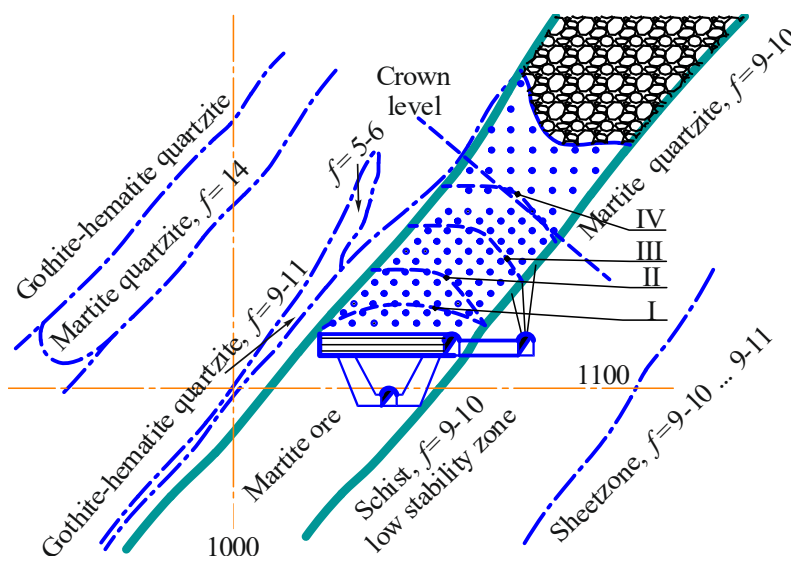

Figure 1. A variant of the room-and-pillar system with formation of an arched crown: a-vertical plane; $b$ - section on axis $8 ; I, I I, I I I, I V$ - stages of forming an arched crown of a stope

The recommended arched crown of a stope is characterized by increased stability as compared to horizontal exposures and decreased probability of casual failures. An arched crown is formed through charging some of deep holes that are within the contour of the future stope. The number and layout of simultaneously charged and blasted holes corresponds to the stage of forming the arched crown of a stope. When forming arched crowns of stopes, principal stress values are distributed according to the classical law of stress distribution in rocks. ANSYS 16.0 is applied to perform calculation of stresses. The results of the stress field calculations for various shapes of arched crowns are given below. The finite element size is $1 \mathrm{~m}$. Stress values on isolines are given in MPa.

Figure 2 provides an example of the calculation results and isolines of principal stresses $\sigma_{1}$ in rocks during the second stage of forming an arched crown in the room-and-pillar variant recommended for the PJSC "Sukha Balka" underground mines. The results of calculating principal stresses $\sigma_{1}$ of rocks when forming an arched crown demonstrate that the value of stresses in the crowns vary depending on the rock pressure value and the curvature radius of the arched crown. The arched crowns with the curvature radius equal to a half of the stope width are the most stable.

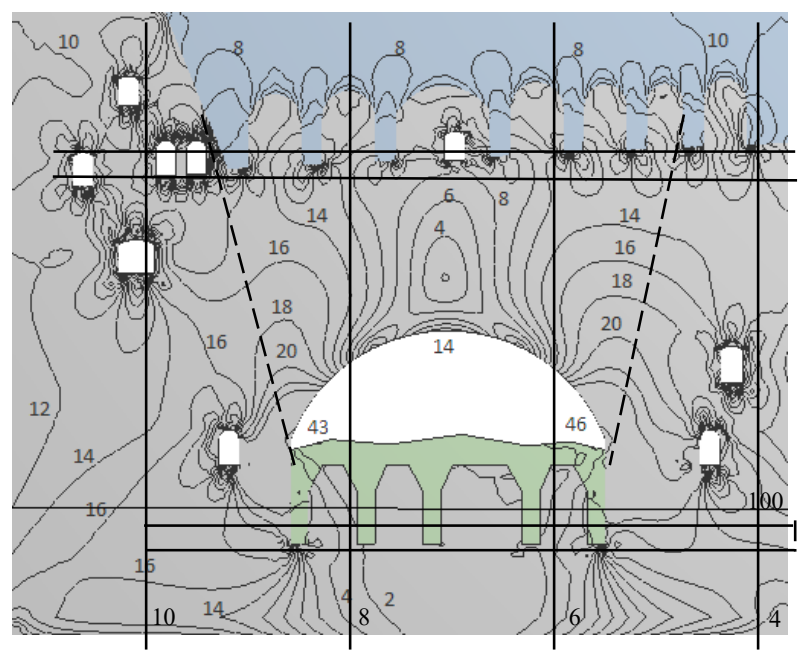

Figure 2. Calculation results and isolines of principal stresses $\sigma_{1}$ in the rock massif when forming the second stage of an arched crown

Analysis of multifactor experiment results enables to determine the universal adaptive indices of a maximum stresses value $\sigma_{1}$ in arched crowns of stopes depending on the mining depth $H_{p}$, a relative crown curvature radius $R_{o}$ and differentiated iron ore hardness $f, \mathrm{MPa}$ :

$$
\begin{aligned}
& \sigma_{1}=\left(0.2880 \ln \left(H_{p}\right)-1.0405\right) \cdot\left(6.636 \ln \left(R_{o}\right)+\right. \\
& +9.4) \cdot\left(-5.83 \cdot 10^{-3} f^{2}+0.1325 f+0.4582\right) .
\end{aligned}
$$

According to the calculation results, arched crowns of stopes experience tension stresses. The largest values of stresses are observed in the arch springs; however, they are far from being destructive. Unlike horizontal crowns, the central part of the arched crowns experiences almost no tension stresses that are considered the most dangerous for stope exposures. Absence of tensile stresses in arched crowns of stopes leads to their increased stability, other factors being equal. Increased stability of arched crowns in compensating rooms and stopes will result in decreased number of destroyed holes over the stope zone caused by possible partial or complete failure of crowns. Maintenance of deep holes will enhance massif breaking indices due to increased quality of muck crushing and corresponding decrease in oversize yield. Increased quality of rock massif breaking will improve muck ore indices and rich muck extraction from stopes. 


\section{CONCLUSIONS}

The increased mining depth results in considerable rock pressure growth. Thus, special requirements are placed on stability of exposed stopes as well as stability of crown exposures of stopes and compensating rooms when designing stopes at great depths.

In this connection, for the case of mining rich iron ores by sublevel caving systems the authors recommend that vertical and inclined compensating rooms be wider applied to Kryvbas underground ores. When rich iron ores are mined by the room-and-pillar systems at depths of over $1300 \mathrm{~m}$, it is advisable to use tent and arched crowns that provide maximum stability under high rock pressure.

Formation of arched crowns in the PJSC "Sukha Balka" underground mines will enable to reduce losses of deep holes in crowns from $18-21$ to $11-15 \%$.

\section{ACKNOWLEDGEMENTS}

The authors would like to express their sincere gratitude to the management of PJSC "Sukha Balka" for assistance in conducting the research and implementing its results.

\section{REFERENCES}

ASTM D7012-07e1. (2009). Standard test method for compressive strength and elastic moduli of intact rock core specimens under varying states of stress and temperatures. West Conshohocken, US: American Society for Testing and Materials.

Bondarenko, V.I., Kovalevskaya, I.A., Simanovich, G.A., \& Snigur, V.G. (2013). Analitiko-eksperimentalnye issledovaniya ustoichivosti vyemochnykh vyrabotok $i$ raschet parametrov krepezhnoi sistemy. Dnipro: LizunovPres.

Cała, M., Stopkowicz, A., Kowalski, M., Blajer, M., Cyran, K., \& D'obyrn, K. (2016). Stability analysis of underground mining openings with complex geometry. Studia Geotechnica et Mechanica, 38(1), 25-32. https://doi.org/10.1515/sgem-2016-0003

Das, A.J., Mandal, P.K., Bhattacharjee, R., Tiwari, S., Kushwaha, A., \& Roy, L.B. (2017). Evaluation of stability of underground workings for exploitation of an inclined coal seam by the ubiquitous joint model. International Journal of Rock Mechanics and Mining Sciences, (93), 101-114. https://doi.org/10.1016/j.ijrmms.2017.01.012
Esterhuizen, G.S., Dolinar, D.R., Ellenberger, J.L., Prosser, L.J., \& Iannacchione, A.T. (2007). Roof stability issues in underground limestone mines in the United States. In Proceedings of the $26^{\text {th }}$ international conference on ground control in mining. (pp. 320-327). Morgantown, United States: West Virginia University.

Iannacchione, A.T., Batchler, T., \& Marshall, T. (2004) Mapping hazards with microseismic technology to anticipate roof falls - a case study. In Proceedings of the $23^{\text {th }}$ International Conference on Ground Control in Mining (pp. 327-333). Morgantown, United States: Pittsburgh Research Laboratory.

Kalinichenko, O.V. (2015). Udoskonalennia kontseptsii upravlinnia napruzheno-deformovanym stanom hirskoho masyvu pry pidzemnykh hirnychykh robotakh. Collection of research papers of SP "Research Mining Institute", 104-111.

Kriev, Yu.K., \& Kriev, I.Yu. (2005). Nesushchaya sposobnost' nadsvodovoi chasti vyrabotok, stroyashchikhsia v skalnykh porodakh. Gornyy Zhurnal, (4), 48-50.

Malakhov, G.M. (1990). Upravlenie gornym davleniem pri razrabotke rudnykh mestorozhdenii Krivorozhskogo basseina. Kyiv: Naukova dumka.

Radouane, N., Boukelloul, M., \& Fredj, M. (2015). Stability analysis of underground mining and their application on the mine Chaabte El Hamra, Algeria. Procedia Earth and Planetary Science, (15), 237-243. https://doi.org/10.1016/j.proeps.2015.08.058

Stupnik, N., \& Kalinichenko, V. (2012). Parameters of shear zone and methods of their conditions control at underground mining of steep-dipping iron ore deposits in Kryvyi Rig basin. Geomechanical Processes During Underground Mining, 15-17. https://doi.org/10.1201/b13157-4

Stupnik, N.I., Kalinichenko, V.A., Pysmennyi, S.V., \& Kalinichenko, Ye.V. (2016). Obosnovanie parametrov ochistnoi kamery parabolicheskoi formy pri otrabotke zheleznykh rud $\mathrm{v}$ neustoichivykh porodakh. Hirnychyi Visnyk, (10), 7-12.

Talobre, J.A. (1967). La mécanique des roches. Paris, France: Dunod.

Tsarikovskii, V.V., Sakovich, V.V., Kishkin, P.I., Artemenko, A.F., \& Migul, A.F. (1994). Opredelenie geometricheskikh parametrov kamernykh sistem razrabotki v Krivbasse so svodoobraznoy i shatrovoy formami obnazhenia potolochin. Kryvyi Rih: NIGRI.

Vybor i obosnovanie ustoichivykh form potolochin pri dobyche zheleznykh rud na bolshikh glubinakh. (2017). Kryvyi Rih: ITS KNU.

\section{ВИБІР ТА ОБГРУНТУВАННЯ СТІЙКИХ ФОРМ СТЕЛИН ПРИ ВИДОБУТКУ ЗАЛІЗНИХ РУД НА ВЕЛИКИХ ГЛИБИНАХ}

\section{М. Ступнік, О. Калініченко, В. Калініченко, С. Письменний, О. Моргун}

Мета. Вибір та обгрунтування стійких форм стелин за рахунок встановлення закономірностей впливу гірського тиску на їх стійкість залежно від форми стелин, глибини розробки та міцності залізних руд.

Методика. У даній роботі розрахунок напружень і деформацій гірського масиву виконано методом кінцевих елементів за допомогою програмного комплексу Ansys 16.0. Для побудови епюр напружень і деформацій методом кінцевих елементів над моделлю було проведено тріангуляцію 3D-моделі з розміром сторони 2 м. Згідно з умовами експерименту, були сформовані моделі з горизонтальною, шатровою, склепіннеподібною і похилою покрівлею камер, кут нахилу яких варіювався в широких межах. Прийняті величини тиску гірських порід на рудний масив відповідали гірничотехнічним умовам відпрацювання родовищ Криворізького басейну на глибинах від 1200 до 1700 м.

Результати. Отримано розрахункові значення величин максимальних напружень в стелинах очисних камер залежно від глибини розробки, величини гірського тиску, кута нахилу стелини, міцності залізних руд і відносного радіуса кривизни склепіннеподібної стелини. Встановлено, що при відпрацюванні багатих залізних руд на великих глибинах системами підповерхового обвалення необхідно застосовувати вертикальні й похилі компенсаційні камери. Виявлено, що при відпрацюванні багатих залізних руд камерними системами розробки на значних глибинах ключовою вимогою, що забезпечує максимальну стійкість в умовах високого гірського тиску, $\epsilon$ перехід на шатрові та склепінчасті стелини. 
Наукова новизна. Доведено, що інтегральний показник величини максимальних напружень у міжповерхових ціликах змінюється в межах від -10 до +32 МПа на глибинах понад 1200 м та знаходиться в поліноміальнологарифмічній залежності від фізико-механічних властивостей рудного масиву, залежить від геометричних параметрів склепіння і при його склепіннеподібній формі набуває мінімальних значень, дозволяючи формувати стійкі відслонення міжповерхових ціликів на глибинах до 2000 м.

Практична значимість. Розроблено методичні рекомендації «Вибір та обгрунтування стійких форм стелин при видобутку залізних руд на великих глибинах» для умов шахт ПрАТ «Свраз Суха Балка» і шахти «Родіна» ПАТ «Кривбасзалізрудком».

Ключові слова: руда, підземна розробка, стелина, відслонення, напруження, стійкість

\title{
ВЫБОР И ОБОСНОВАНИЕ УСТОЙЧИВЫХ ФОРМ ПОТОЛОЧИН ПРИ ДОБЫЧЕ ЖЕЛЕЗНЫХ РУД НА БОЛЬШИХ ГЛУБИНАХ
}

\author{
Н. Ступник, Е. Калиниченко, В. Калиниченко, С. Письменный, А. Моргун
}

Цель. Выбор и обоснование устойчивых форм потолочин за счет установления закономерностей влияния горного давления на их устойчивость в зависимости от формы потолочин, глубины разработки и крепости железных руд.

Методика. В данной работе расчет напряжений и деформаций горного массива выполнялся методом конечных элементов посредством программного комплекса Ansys 16.0. Для построения эпюр напряжений и деформаций методом конечных элементов над моделью было проведено триангуляцию 3D-модели с размером стороны 2 м. Согласно условиям эксперимента, были сформированы модели с горизонтальной, шатровой, сводообразной и наклонной кровлей камер, угол наклона которых варьировался в широких пределах. Принятые величины давления горных пород на рудный массив соответствовали горнотехническим условиям отработки месторождений Криворожского бассейна на глубинах от 1200 до 1700 м.

Результаты. Получены расчетные значения величин максимальных напряжений в потолочинах очистных камер в зависимости от глубины разработки, величины горного давления, угла наклона потолочины, крепости железных руд и относительного радиуса кривизны сводообразных потолочин. Установлено, что при отработке богатых железных руд на больших глубинах системами подэтажного обрушения необходимо использовать вертикальные и наклонные компенсационные камеры. Выявлено, что при отработке богатых железных руд камерными системами разработки на значительных глубинах ключевым требованием, обеспечивающим максимальную устойчивость в условиях высокого горного давления, является переход на шатровые и сводчатые потолочины.

Научная новизна. Доказано, что интегральный показатель величины максимальных напряжений в междуэтажных целиках меняется в пределах от -10 до +32 МПа на глубинах более 1200 м, находится в полиномиально-логарифмической зависимости от физико-механических свойств рудного массива, зависит от геометрических параметров потолочины и при ее сводообразной форме приобретает минимальные значения, позволяя формировать устойчивые обнажения междуэтажных целиков на глубинах до 2000 м.

Практическая значимость. Разработаны методические рекомендации «Выбор и обоснование устойчивых форм потолочин при добыче железных руд на больших глубинах» для условий шахт ЧАО «Евраз Суха Балка» и шахты «Родина» ПАО «Кривбассжелезрудком».

Ключевые слова: руда, подземная разработка, потолочина, обнажения, напряжения, устойчивость

\section{ARTICLE INFO}

Received: 14 May 2018

Accepted: 11 November 2018

Available online: 24 November 2018

\section{ABOUT AUTHORS}

Mykola Stupnik, Doctor of Technical Sciences, Rector of the Kryvyi Rih National University, 11 Matusevycha St, 50027, Kryvyi Rih, Ukraine. E-mail: mstupnik2012@gmail.com

Olena Kalinichenko, Candidate of Economic Sciences, Associate Professor of the Department of Underground Mining of Mineral Deposits, Kryvyi Rih National University, 11 Matusevycha St, 50027, Kryvyi Rih, Ukraine. E-mail: elenakalinichenko_v@,mail.ru

Vsevolod Kalinichenko, Doctor of Technical Sciences, Head of the Department of Underground Mining of Mineral Deposits, Kryvyi Rih National University, 11 Matusevycha St, 50027, Kryvyi Rih, Ukraine. E-mail: vsevolod921@mail.ru

Serhii Pysmennyi, Candidate of Technical Sciences, Associate Professor of the Department of Underground Mining of Mineral Deposits, Kryvyi Rih National University, 11 Matusevycha St, 50027, Kryvyi Rih, Ukraine. E-mail: psvknu@gmail.com

Oleksandr Morhun, Head of the Organization Management and Production Processes Support of the PJSC "Sukha Balka", 5 Konstytutsiina St, 50029, Kryvyi Rih, Ukraine. E-mail: amorgun@gmail.com 